\title{
FOSSIL VERTEBRATES AND PALEOMAGNETISM UPDATE OF ONE OF THE EARLIER STAGES OF CAVE EVOLUTION IN THE CLASSICAL KARST, SLOVENIA: PLIOCENE OF ČRNOTIČE II SITE AND RAČIŠKA PEČINA CAVE
}

\author{
FOSILNI VRETENČARJI IN PALEOMAGNETNA POSODOBITEV \\ ENE OD ZGODNJIH FAZ RAZVOJA JAM NA KLASIČNEM KRASU, \\ SLOVENIJA: PLIOCEN ČRNOTIČ II IN RAČIŠKE PEČINE
}

\author{
Ivan HORÁČEK ${ }^{1}$, Andrej MIHEVC'², Nadja ZUPAN HAJNA², \\ Petr PRUNER ${ }^{3} \&$ Pavel BOSÁK ${ }^{2,3}$
}

\begin{abstract}
UDC 551.44:550.38(497.4 Črnotiče) Ivan Horáček, Andrej Mihevc, Nadja Zupan Hajna, Petr Pruner \& Pavel Bosák: Fossil vertebrates and paleomagnetism update of one of the earlier stages of cave evolution in the Classical karst, Slovenia: Pliocene of Črnotiče II site and Račiška pečina Cave

For the first time in the Classical Karst, paleontological data enabled to match the magnetostratigraphic record precisely with the geomagnetic polarity timescale in two studied sites: (i) a series of speleothems alternating with red clays in Račiška pečina Cave (Matarsko podolje), and (ii) an unroofed paleocave of the Črnotiče II site (Podgorski kras Plateau) completely filled by fluvial clastic sediments covered by speleothems. The later sites are also characterized by a rich appearance of fossil tubes of autochthonous stygobiont serpulid Marifugia cavatica. The vertebrate record is composed mostly of enamel fragments of rodents and soricomorphs. Absence of rootless arvicolids as well as taxonomic composition of the mammalian fauna suggests the Pliocene age of both sites. For (i) Račiška pečina (with Apodemus, cf. Borsodia) it was estimated to middle to late MN17 (ca 1.8-2.4 Ma), while (ii) the assemblage from Črnotiče II (with Deinsdorfia sp., Beremedia fissidens, Apodemus cf. atavus, Rhagapodemus cf. frequens, Glirulus sp., Cseria sp.) is obviously quite older: MN15-MN16 (ca 3.0-4.1 Ma). In respect to congruence of biostratigraphic and paleomagnetic data and a reliable sedimentary setting of the samples we propose to apply the respective datum also as the time of one ancient speleogenetic phase in the Classical Karst.
\end{abstract}

Keyword: cave sediments, magnetostratigraphy, mammals, Soricomorpha, Rodentia.
Izvleček UDK 551.44:550.38(497.4 Črnotiče) Ivan Horáček, Andrej Mihevc, Nadja Zupan Hajna, Petr Pruner \& Pavel Bosák: Fosilni vretenčarji in paleomagnetna posodobitev ene od zgodnjih faz razvoja jam na Klasičnem krasu, Slovenija: pliocen Črnotič II in Račiške pečine

$\mathrm{Na}$ Klasičnem krasu so paleontološki podatki prvič omogočili uskladitev magnetostratigrafskih podatkov $\mathrm{Z}$ geomagnetno polarizacijsko časovno skalo. Na dveh proučenih mestih: (i) v profilu s sigami in rdečimi ilovicami v Račiški pečini (Matarsko podolje) in (ii) v brezstropi jami, lokacija Črnotiče II (Podgorski kras), ki je zapolnjena s fluvialnimi klastičnimi sedimenti prekritimi s sigo. Ta zadnja lokacija se odlikuje z bogatim nahajališčem fosilnih cevčic jamskega serpulida Marifugia cavatica. Ostanke vretenčarjev predstavljajo predvsem fragmenti sklenine glodalcev in soricomorfov. Odsotnost voluharic brez zobnih korenin, kakor tudi taksonomska sestava sesalske favne, kažeta na pliocensko starost obeh lokacij. Favna iz (i) Račiške pečine (z Apodemus, cf. Borsodia) pripada srednji do pozni bioconi MN17 (ca.1.8-2.4 Ma). Fosilna združba (ii) iz Črnotič II (z Deinsdorfia sp., Beremedia fissidens, Apodemus cf. atavus, Rhagapodemus of. frequens, Glirulus sp., Cseria sp.) je očitno precej starejša in pripada bioconi MN15-MN16 (ca 3.0-4.1 Ma). Z upoštevanjem skladnosti biostratigrafskih in paleomagnetnih datacijskih podatkov in verodostojnega sedimentacijskega okvirja vzorcev predlagamo, da se tako dobljeno datacijo uporabi tudi kot čas, ko se je končala ena od starih speleogenetskih faz na Klasičnem krasu.

Ključne besede: jamski sedimenti, magnetostratigrafija, sesalci, Soricomorpha, Rodentia.

\footnotetext{
${ }^{1}$ Department of Zoology, Faculty of Science, Charles University, Viničná 7, 12844 Praha, Czech Republic, e-mail: horacek@natur.cuni.cz

${ }^{2}$ Karst Research Institute, SRC SASA, Titov trg 2, 6230 Postojna, Slovenia, e-mail: mihevc@zrc-sazu.si; zupan@zrc-sazu.si

${ }^{3}$ Institute of Geology AS CR, v.v.i., Rozvojová 269, 16500 Praha 6, Czech Republic, e-mail: pruner@gli.cas.cz; bosak@gli.cas.cz

Received/Prejeto: 02.10 .2007
} 


\section{INTRODUCTION}

The sedimentary fill of caves (cave sediments) in the Classical Karst of SW Slovenia was expected not to be much older than 350 ka (Gospodarič, 1972, 1974, 1976,1977, $1981,1984,1985,1988)$. This view was based on results of sedimentologic research, archeologic and paleontologic finds, and on numerical dating $\left(\right.$ like ${ }^{14} \mathrm{C}, \mathrm{Th} / \mathrm{U}$, ESR; a.o., Franke \& Geyh, 1971; Ikeya et al., 1983; Ford \& Gospodarič, 1989) from many sedimentary profiles in Postojna, Planina, Križna, Škocjan and other caves. Gospodarič (1988) distinguishes different deposition phases of cave sediments related to glacioeustatic oscillations of the Adriatic Sea and the global paleoclimate evolution during Pleistocene.

Later researches in several caves of Notranjska and Primorska karst regions (central and western Slovenia) indicate the existence of many flowstones older than 350 ka, i.e. out of limit of the method (Zupan, 1991; Mihevc \& Lauritzen, 1997; Mihevc, 2001). Geomorphologic comparative method shows that many accessible caves in the Classical Karst are at least of the Pliocene age (Mihevc, 1996, 2001). Nevertheless, paleontological finds indicate only Pleistocene age of fauna in studied cave sediments (Brodar, 1952, 1958, 1966, 1970; Rakovec, 1958; Aguillar et al., 1998)

Only the application and interpretation of palaeomagnetic analyses and magnetostratigraphy of cave sediments, both clastic and chemogenic, started in the Classical Karst in 1997, indicate the substantial change in the lower limit of cave fill deposition (Bosák et al., 1998, 1999, 2000a, b, 2003; 2004a, b; Šebela \& Sasowsky, 2000; Pruner \& Bosák, 2001; Mihevc et al., 2002; Sasowsky et al., 2003; Zupan Hajna et al., 2005, 2007). Magnetostratigraphy data and the arrangement of obtained magnetozones often indicate fill ages of more than $1.77 \mathrm{Ma}$ with possibility of a lower limit even more than $5 \mathrm{Ma}$ (Bosák et al., 1998). The interpretation of magnetostratigraphy is based on the matching of interpreted results with the global geomagnetic polarity scale (GPTS; Cande \& Kent, 1995) and only offers the correlative ages (sensu Colman \& Pierce, 2000). The proper correlation of obtained magnetostratigraphy with the GPTS is possible only in the combination with other dating methods (numerical or calibrate), and especially with paleontological dates (Bosák, 2002; Bosák et al., 2003). Nevertheless, paleontological data for the calibration with the GPTS have been missing, until the first finds of mammal remains in the Račiška pečina in 2003 (Bosák et al., 2004b) and subsequent discovery in the Črnotiče II profile in 2005-2006.

Here, we are using the term Pliocene in a traditional sense. The Plio-Pleistocene boundary is located at $1.8 \mathrm{Ma}$ (Aguirre \& Pasini, 1985), close to the base of Olduvai normal subchron (C2n) at $1.77 \mathrm{Ma}$ (within the Matuyama Chron). The newly proposed Plio-Pleistocene boundary at about 2.6 Ma (close to Matuyama/Gauss boundary, base of Chron C2Ar at 2.581 Ma and at the base of the MIS 103 at $2.588 \mathrm{Ma}$; Ogg, 2007) has not yet been approved by the IUGS.

\section{DESCRIPTION OF SITES}

The Classical Karst of W Slovenia belongs to Adriatic-Dinaric Carbonate Platform of the Outer Dinarids composed of shallow marine Cretaceous and Paleogene carbonate rocks (cf. e.g., Otoničar, 2007). The Eocene deep-marine siliciclastics (flysch) encircle and cover the carbonate plateau. Complicated imbricate structure (the alternation of flysch and limestone thrust slices) parallel to the Dinaric direction has been formed since Oligocene. Karst landscape of the region is characterized by extensive leveled surfaces, blind valleys at limestone/flysch contacts, and old caves in places dissected by younger shafts. Some caves were uncovered at the present surface by chemical denudation (unroofed caves sensu Mihevc 1996, for details see Mihevc 2001). The origin of shafts is connected with substantial drop of piezometric level, which now lies about $200 \mathrm{~m}$ below the surface. Shafts are either empty or filled with Pleistocene sediments (e.g., Rakovec 1958; Brodar 1958).

There are several karst plateaus in the area (Fig. 1). The largest is Kras, the NW - SE trending region along the Golf of Trieste (Adriatic Sea) from the Vipava Valley in the NE up to Friuli-Venezia Giulia lowlands and the Soča River in the NW (Fig. 1). Its central part lies at 200 to 500 m a.s.l. (for more details see Kranjc, 1997). Matarsko podolje is situated to the SE of the Kras. Its karst landscape was formed by denudation on the NE dipping limestone and dolomites at the elevations of 500-700 m a.s.l. Allogenic rivers at the contact with flysch form several blind valleys with traces of constant tectonic uplift (Mihevc, 2004). Podgorski kras Plateau in the S edge of the Kras is widely extended levelled plateau (440 $\mathrm{m}$ a.s.l.) at the foothills of the Slavnik Mt. (Mihevc, 2007; Fig. 1). 


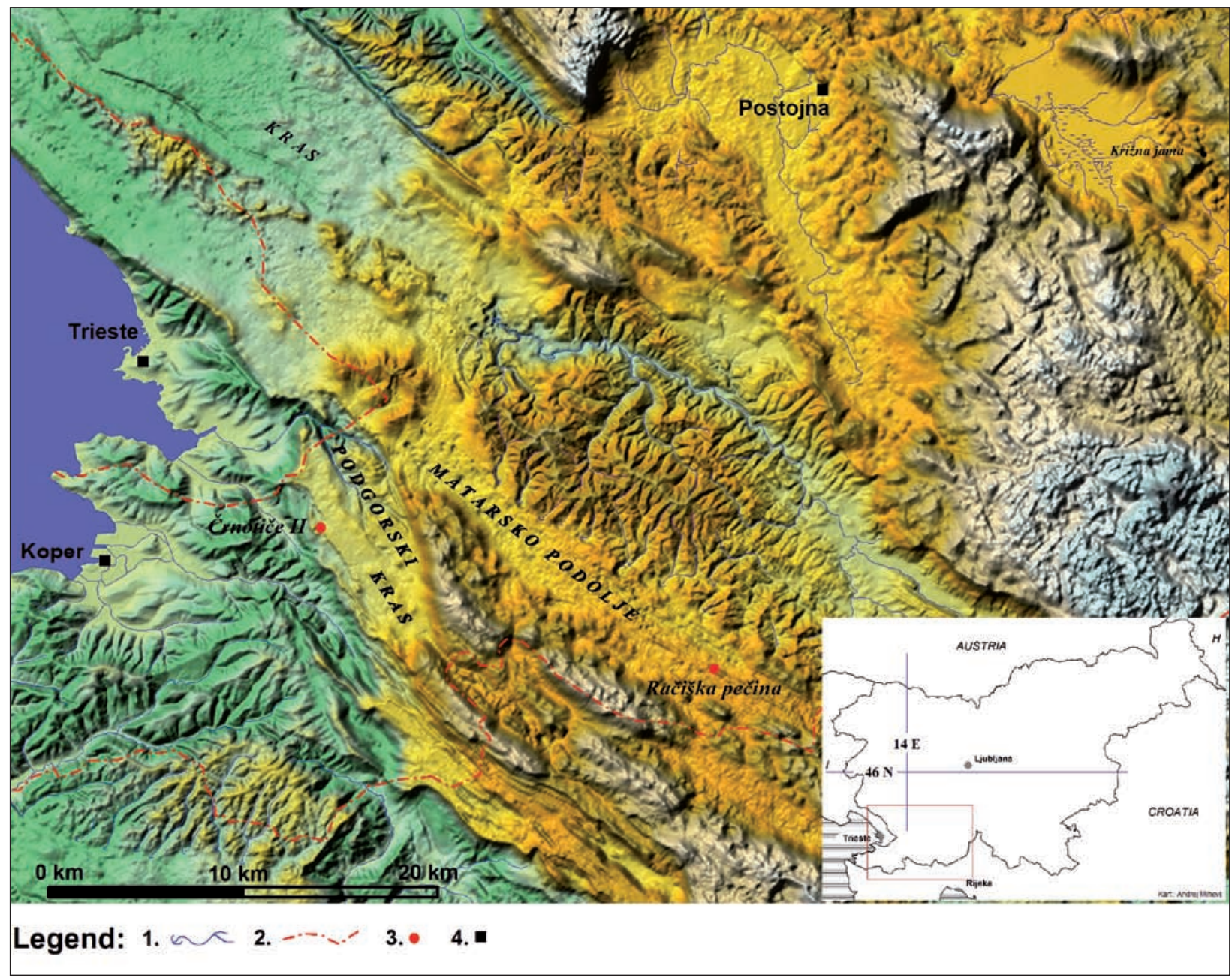

Fig. 1: Position of studied sites.

Denudation surface cuts the Paleocene limestone alternating with thin slices of Eocene flysch that dip north eastwards ( $c f$. Placer 1981). This levelled surface exposes numerous unroofed caves. Large karst springs are located at the plateau foothills at 50-70 m a.s.l.

\section{ČRNOTIČE}

The Črnotiče and Črni kal quarries are situated on the western margin of the Podgorski kras. In both quarries during excavations numerous caves have been opened, most of them completely filled by sediments (see review in Bosák et al., 1999, 2004a; Mihevc, 2007). Dating of calcite cement in gravels rich in large mammal bones yielded age of $211 \pm 45 \mathrm{ka}$ in one shaft of the Črnotiče Quarry (Mihevc, 2001). Caves in the Črni kal Quarry contained Paleolithic tools, Pleistocene large mammals (Rakovec, 1958; Brodar, 1958), and Middle and Late Pleistocene small mammals (Aguilar et al., 1998). Carbonate cement of gravel fill of one shaft was dated to $143 \pm 13 \mathrm{ka}$ (Mihevc, 2001). Palaeomagnetic analysis was used to date pale- okarst site of Črnotiče I in the Črni kal Quarry (Bosák et al., 1999), a part of an extensive cave filled with about $1.75 \mathrm{~m}$ thick banded sandy cave stromatolite intercalated with red clays covering eroded surface of older massive and highly recrystallized speleothems. Palaeomagnetic analysis indicates the age more than $1.77 \mathrm{Ma}$. The finds of problematic fish teeth are still not determined.

Črnotiče I and II sites belong to one paleocave system, which started to be successively opened since 1990 . This was about $150 \mathrm{~m}$ long relic of cave formed by an allogenic river. The extensive passage had the diameter of about $10 \mathrm{~m}$ with the dip in the NW - SE direction. In the eastern part, the passage was unroofed, but in the western part the ceiling has been still preserved. The passage was entirely filled by cave sediments deposited over massive flowstones, several metres thick. Gravels were preserved and in places mixed up with sand and clay. Laminated yellow brown clays to silts contained fragments of speleothems. Reddish clays composed the upper part of profiles. 
The studied profile (unroofed cave, Črnotiče II site) was more than $17 \mathrm{~m}$ high and from 4 to $7.5 \mathrm{~m}$ wide. Lower nine metres were composed of cyclically arranged cave sediments. It was divided by an expressive erosion boundary into two parts. The lower one was built of multicoloured clays and silts overlain by upwards fining fluvial cycles composed of micro conglomerates to conglomerates (clay and silt clasts), which sometimes pass to sands. Individual cycles were separated by thin interbeds of clays to silts. The upper part, above uneven erosion boundary, consisted of laminated to banded silts, clays and very fine-grained silty sands. The clastic fill was covered (above $9 \mathrm{~m}$ up to the surface) by speleothems, and collapsed speleothem and limestone blocks with some terra rossa-like red clays at the base (Fig. 2). Cave walls built of Palaeocene limestone with scallops were covered by tubes of fresh water stygobiont worm Marifugia cavatica Absolon et Hrabě, 1930 about $3 \mathrm{~m}$ above the quarry floor (Fig. 2; Mihevc, 2000; Mihevc et al., 2001, 2002). Washed material was obtained from the right lower part of the profile near the cave wall (see Fig. 2). Multicoloured silt and clays deposited from relatively calm cave fluvial environment with medium rates of deposition. The cyclic deposition resulted from repeated sudden and intensive floods eroding already deposited cave sediments. The rate of deposition is expected to be high.

\section{RAČIŠKA PEČINA}

Račiška pečina is situated in the SE part Cave of the Matarsko podolje near the Croatian border (Fig. 1). Cave at about $590 \mathrm{~m}$ a.s.l. developed in Lower Cretaceous carbonate rocks and represents the relic of an old cave system, which part was already unroofed (Ulica pečina Cave and

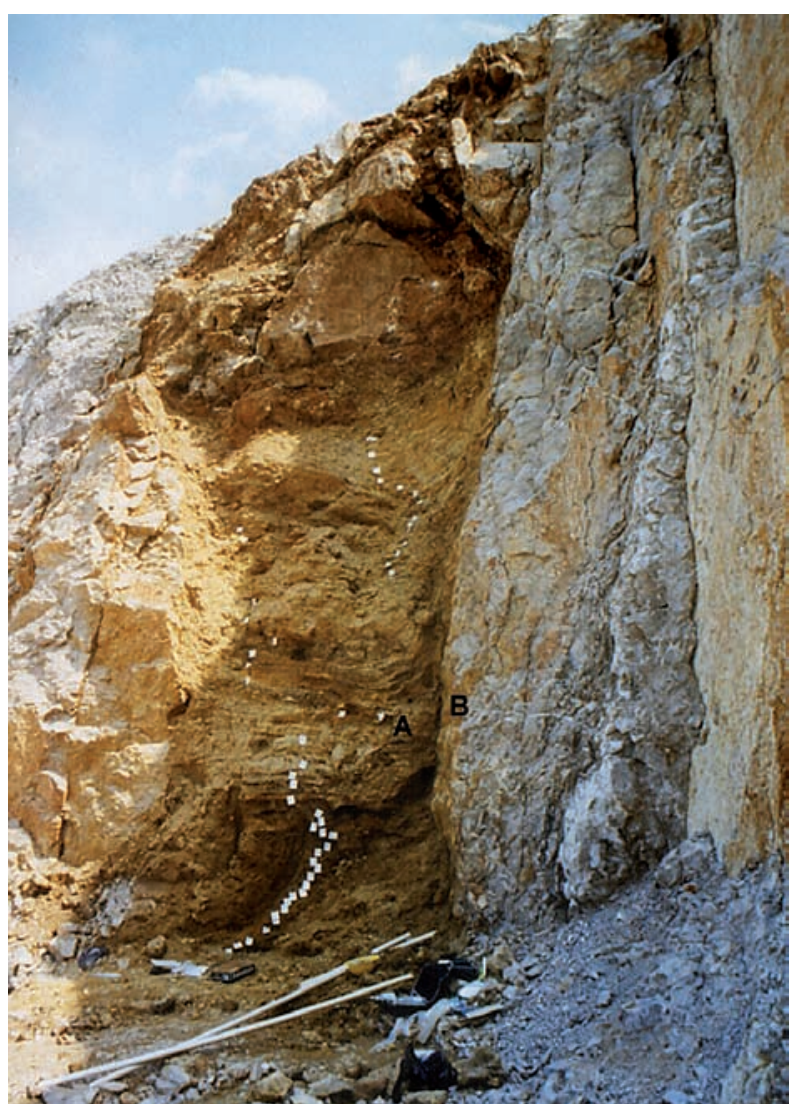

Fig. 2: Photo of the Črnotiče II site with position of paleomagnetic samples (white marks), A - position of sediment with fauna, $B$ position of Marifugia cavatica on cave wall (photo by P. Bosák).

Ulica unroofed cave; Mihevc, 2004). The Račiška pečina is paragenetic or epiphreatic simple southwards dipping gallery, which is mostly over 10 wide, 5-10 m high and

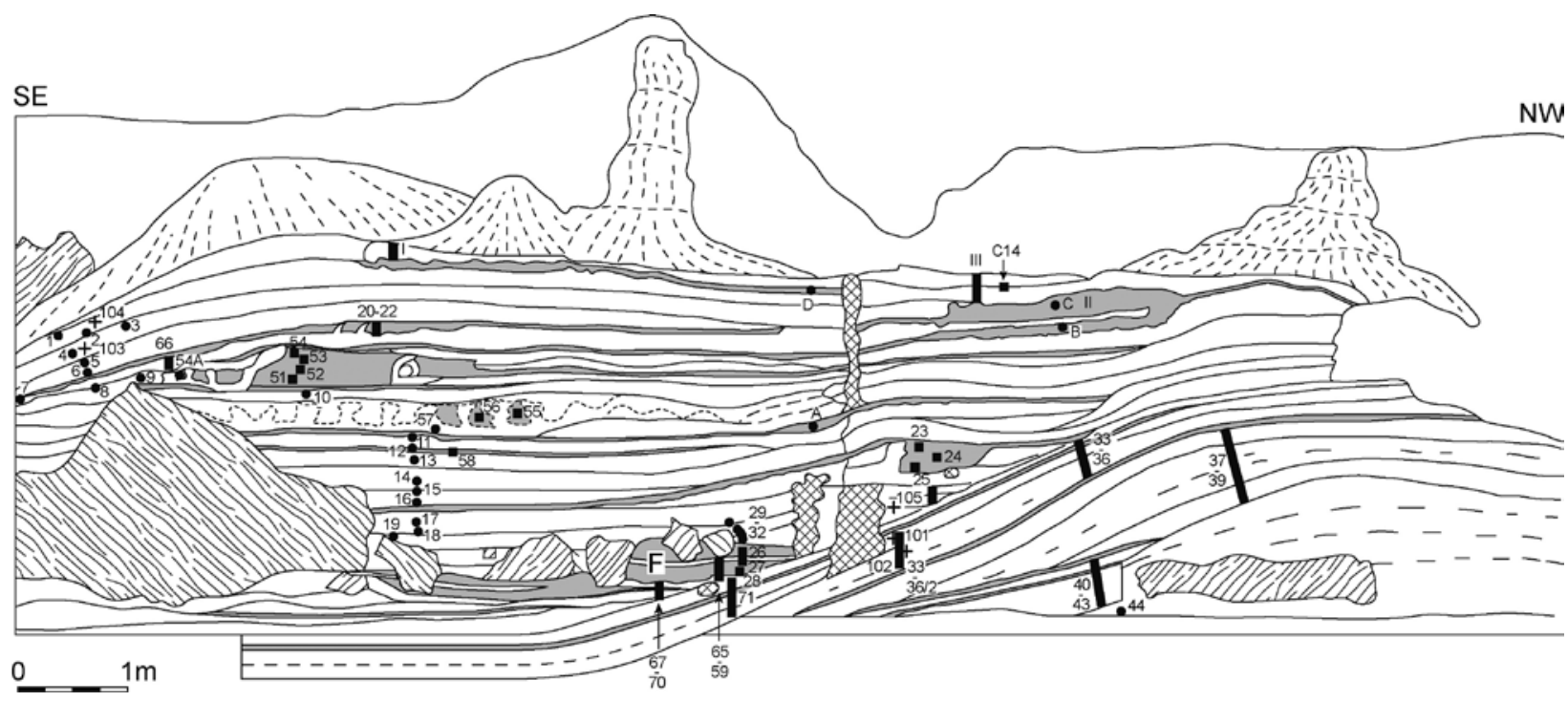

Fig. 3: Drawing of the Račiška pečina profile: F - position of fauna find, grey shading - clays, inclined shading - collapsed blocks of roof, black boxes - paleomagnetic samples, speleothems, black circles - paleomagnetic samples, clays. 
304 m long (Bosák et al., 2004b). On the southern side, the cave terminates with the collapse and sedimentary plug. Clays of unknown thickness covered by massive flowstone form the bottom of the cave. There are traces of Ursus spelaeus on the cave floor (Mihevc, 2003). Remains of Prehistoric pottery were found at the cave entrance. The studied profile represents slightly more than $3 \mathrm{~m}$ high and about $20 \mathrm{~m}$ long cut in the cave fill (Fig. 3 ) uncovered when the cave was adapted as the military magazine. It is situated in the southern part of the cave, about $200 \mathrm{~m}$ from the present entrance.

The composite thickness of sampled profile reaches about $6.5 \mathrm{~m}$. The lower part is built of three sequences, representing the growth stages of a huge vaulted stalagmite (light brown to reddish brown mostly corroded calcite) and containing two angular unconformities (expressed as thin intercalations of red clays) with broken rests of stalagmites on their tops. The upper part consists of sub-horizontal laminated, mostly porous and light-coloured flowstones intercalated by flowstone with gours and red clays and silts. Collapsed roof blocks cover red clays with finds of fauna (F on Fig. 3). The topmost part, in the thickness of several tens of centimetres, is composed of massive flowstone layers with intercalations of brown cave loams containing large bones (mostly Ursus spelaeus). The profile is covered by huge stalagmites, which were not studied.

The samples for paleontological analyses were taken at 4 principal clay horizons. All the described remains were obtained from the layer situated just at the base of the section (F on Fig. 3). Lutitic intercalations represent results of numerous and intensive floods bringing allochthonous material. Clays are well-sieved and represent the deposited suspension of the cave stream load. Very fine-grained sand and silt laminas at the bottom or inside some layers are rare and occur only in clay beds of higher thickness, and indicate flood pulses within one lutitic layer. The character of allogenic lutites can indicate that studied site occurred far from the cave ponor and/or that allogenic stream had to pass through a system of sumps.

\section{MAGNETOSTRATIGRAPHY}

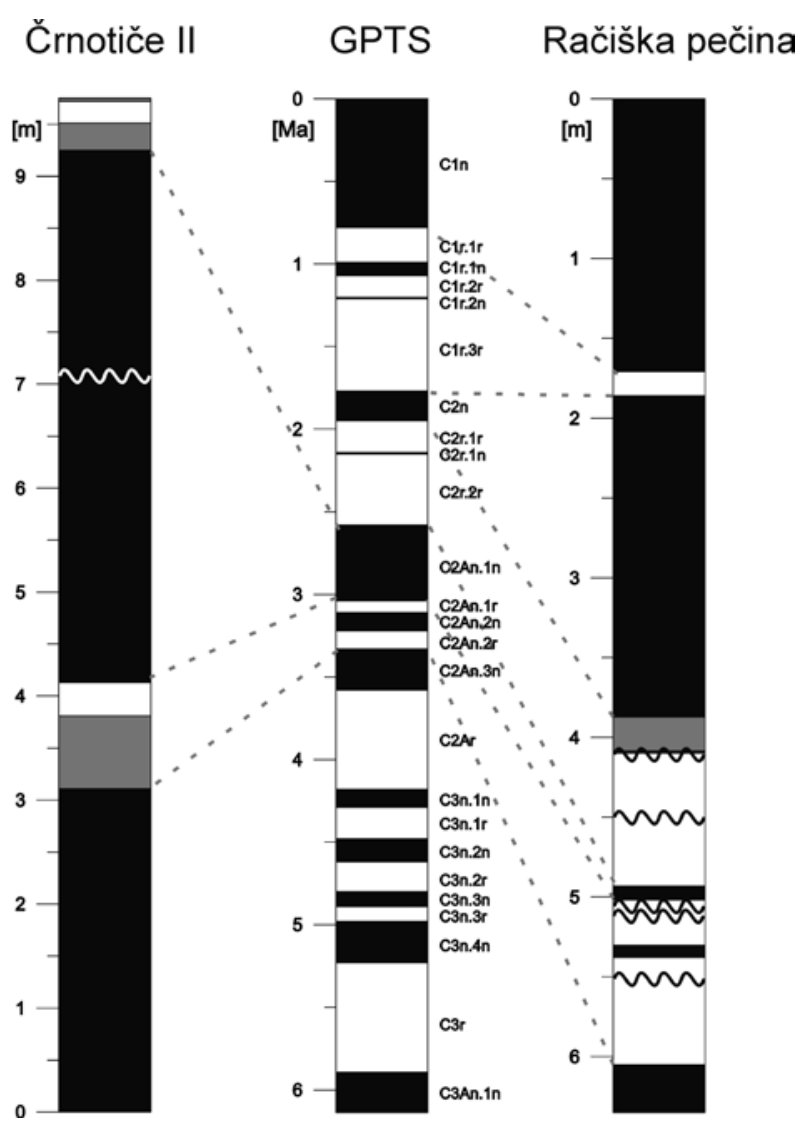

Palaeomagnetic analysis was based on the progressive demagnetisation by alternating field (Schonstedt GSD-1 or LDA-3) or thermal demagnetisation (MAVACS). The natural remanent magnetization, as well as volume magnetic susceptibility was measured on JR-5A or JR-6A spinner magnetometres and KLY-2 or KLY-3 kappabridges. The separation of the respective remanent magnetisation components was carried out by Kirchshvink multi-component analysis (Kirschvink, 1980). The statistics of Fisher (1953) was applied for calculation of mean directions of pertinent remanence components derived by multi-component analysis. For details of sampling and analytical procedure see Bosák et al. (1998, 1999, 2000ab, 2003, 2004a).

\section{ČRNOTIČE II SITE}

Both parts of the profile show normal polarity magnetozones. One narrow reverse polarity subzone is situated in the middle part of the profile. Another narrow reverse polarity subzone, documented on one sample only, is situated in the upper part above the erosion surface (Fig. 4).

Fig. 4: Correlation of magnetostratigraphic logs of the Črnotiče II site (left) and the Račiška pečina (right; simplified) with the GPTS (Cande \& Kent 1995; center): black - normal polarity, grey - transient polarity, white - reverse polarity, - principal hiatus. 
The matching of obtained magnetozone arrangements with the GPTS indicated the age of sediments more than $1.77 \mathrm{Ma}$ (base of the C2n Olduvai subchron). The fill most probably belongs to the Gauss Chron (ca 2.6 to 3.6 $\mathrm{Ma}$ ) or the other normal subchron (within the Gilbert Chron; 4.18-4.29 or 4.48-4.62 Ma; Bosák et al., 2004a).

\section{RAČIŠKA PEČINA}

Clear paleontological data enabled, for the first time in the Classical Karst, to fix the arrangement of interpreted magnetozones with the GPTS. Fauna belonging to the MN17 biozone was found in red clays in the depth interval of 3.79 to $4.05 \mathrm{~m}$ (Fig. 3 and 4). Therefore the base of long normal polarized magnetozone terminating within the interval with fauna was identified with the base of C2n Olduvai subchron (1.95 Ma; Bosák et al., 2004b; Fig. 4). Normal polarized magnetozone above this boundary belongs to the Olduvai subchron (1.770-1.950 Ma). Short reverse polarized magnetozone represents some part of the Matuyama Chron. Normal polarized top of the profile belongs to Brunhes Chron (C1n, younger than 0.780 $\mathrm{Ma})$, which corresponds with the character of fauna in loam interbeds. The interpretation of magnetostratigraphy below the Olduvai base is not completely clear. The geometry of obtained magnetozones is changed as compared with subchrons on the GPTS due to numerous principal breaks in deposition. Nevertheless, we expect the correlation with the lower part of the Matuyama Chron (2.150-2.581 Ma) and the Gauss Chron (2.581$3.58 \mathrm{Ma}$ ). The comparison with the GPTS can indicate duration of individual breaks in deposition in 150-250 $\mathrm{ka}$, in the lower part probably substantially more (Bosák et al., 2004b).

\section{PALEONTOLOGY}

Washing of samples taken from the Račiška pečina (about $40 \mathrm{~kg}$ from site marked F on Fig. 3) and Črnotiče II site (300 kg from site marked A on Fig. 2) provided rich material of microscopic fragments of vertebrate fossil remains. The appearance of the remains, their taphonomical characteristics and to a considerable degree also taxonomic composition was quite similar in both sites.

As a rule the individual fossil rests are corroded and fragmented into quite small pieces. Fossils are covered by thin amorphous fossilization crust rich in $\mathrm{Si}$ (?opal), $\mathrm{Ca}$ and $\mathrm{Cr}$ (microprobe analysis) largely resistant to acid etching. This fact essentially complicated the SEM study. Altered surfaces under the crust are rich in $\mathrm{Ca}, \mathrm{Si}, \mathrm{Fe}$, $\mathrm{Cr}$, but lack $\mathrm{Mn}, \mathrm{Mg}$ and $\mathrm{Al}$ (microprobe analysis). Fossil samples were studied on CAMECA 100 microprobe (Institute of Geology AS CR, v.v.i., Prague) and JEOL 6386 scanning electron microscope (Faculty of Science, Charles University, Prague).

\section{MATERIAL}

\section{Črnotiče II site}

Vast predominance of autochthonous stygobiont serpulid tubes (Marifugia cavatica Absolon et Hrabě, 1930) was detected in the fossil sample. This taxon, patterns of its appearance in the site, and its paleoecologic and stratigraphic meaning has been already discussed (Mihevc, 2000; Mihevc et al., 2001, 2002).

The vertebrate record consists of 58 items, mostly poorly preserved and corroded fragments of teeth enamel.
The best preserved items are figure on Plates 1 to 3. Some of them allow at least a tentative identification.

The list of material is as follows: Non-mammalian remains (15): ?Chondrichthyes indet: 15 small conical and flat lanceolate tooth tips. Mammalian remains: Eulipotyphla (4): Deinsdorfia sp. (2I/1), Beremendia fissides (Petenyi, 1864): M/1, M/2; Rodentia (39): indet. fragments of incisor enamel (15 items), Glirulus aff. pusillus (Heller 1936): $1 \mathrm{M3} /$, Apodemus (Sylvaemus) cf. atavus Heller, 1936: 9 fragments (2 M1/, $1 \mathrm{M} 2 /, 1 \mathrm{M} 3 /, 2 \mathrm{M} / 1,1 \mathrm{M} / 2$, 2M/3), Rhagapodemus cf. frequens Kretzoi, 1959 (1 M/2), Arvicolidae indet. (13 fragments of molar enamel): sp. (cf. "Cseria” carnutina Rabeder 1981), sp. 2 (cf. Mimomys (Cseria s.s.) gracilis).

\section{Račiška pečina}

Totally 74 items were obtained. They were mostly very poorly preserved, fragile, and composed of particularly small fragments of teeth enamel (max. 1-2 mm in size), corroded and without a trace of dentine or cementum (Pl. 4).

The list of material is as follows: Non-mammalian remains ( 7 pieces) were as follows: cf. Potamon (Crustacea), 2 tips of small conical teeth (not identified until now), and 3 pharyngeal pearl teeth of a Cyprinid fish, most probably Barbus sp. Mammalian remains were 67 in number: Rodentia (29 fragments of incisors, 2 fragments of metapodia, 35 fragments of molar enamel of arvicolids): at least 2 spp. (incl. cf. Borsodia), $1 \mathrm{M} / 1$ (enamel): Apodemus (Sylvaemus) sp. - cf. atavus Heller, 1936. 


\section{COMMENTS ON PARTICULAR TAXA}

\section{Non-Mammalia indet. - isolated tooth tips (P1.1:4-6)}

The conical sharply tapered to flat lanceolate tooth tips with sharp lateral blades present a conspicuous element of the fossil samples. The respective structures are covered by a very hard enameloid built by tiny (less than $1 \mu$ in diameter) and densely packed crystallites and filled with compact dentine, in contrast to mammalian teeth not corroded. Until now, we did not succeed in taxonomic identification of these structures. Tentatively, we hypothesize that they might belong to juvenile sharks (probably washed from Eocene marls by the sinking river) or to unknown form of bone fish, eventually. Unfortunately, the extensive comparisons with the taxa available at our disposition did not elucidate the identification which thus remains a task for future study.

\section{Deinsdorfia sp. (Pl. 2:1-2)}

Two lower incisors belonging to a medium sized shrew (roughly of a Sorex araneus size) with a characteris-

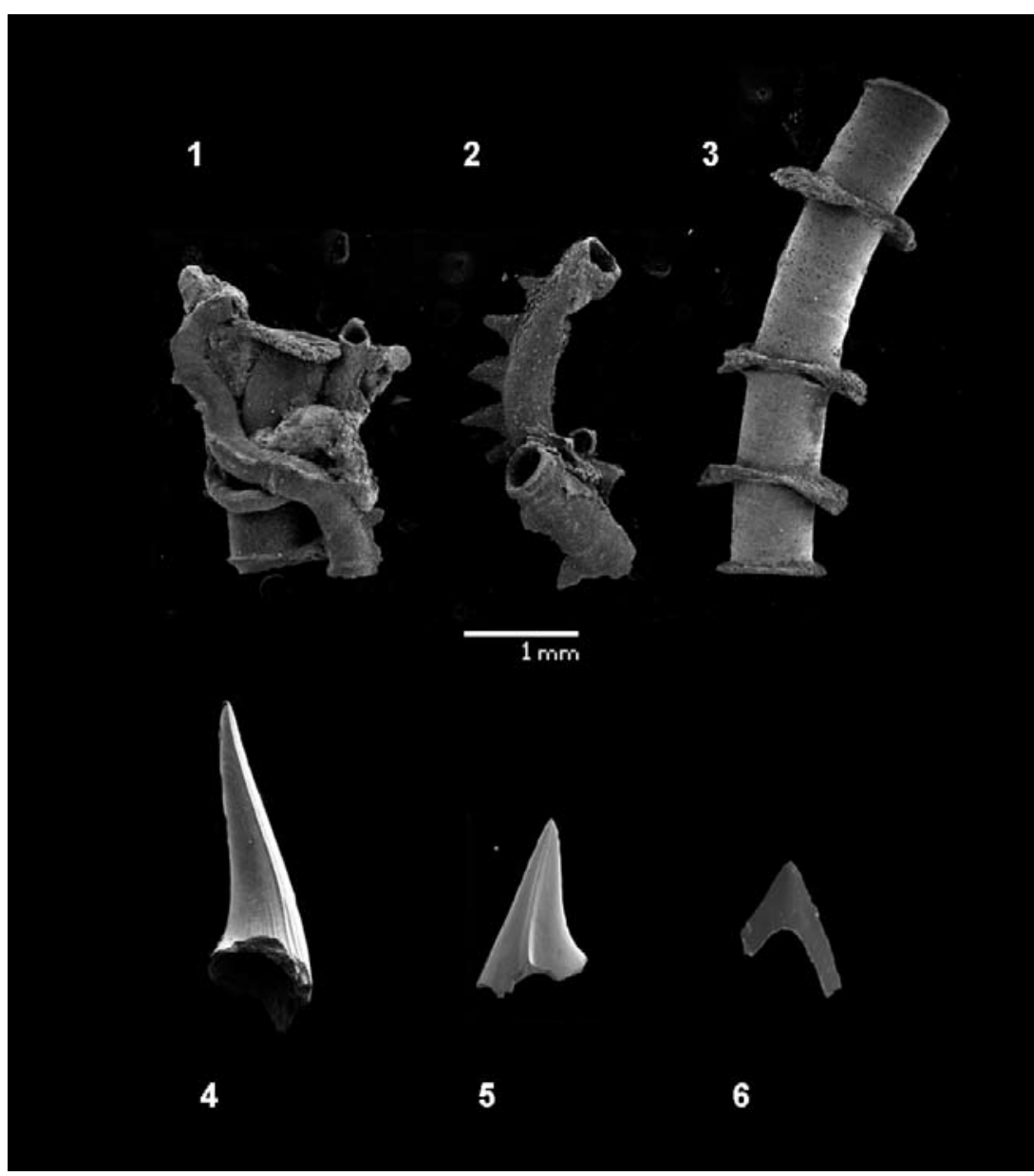

Plate 1: Non-mammalian fossils of the Črnotiče II site: 1-3 - Marifugia cavatica Absolon et Hrabě, 1930; 4-6 - indetermined tooth tips, supposedly a juvenile Chondrichthyes fishes. tic series of rounded cusps at the major occusal ridge and dark colouration at tips belong undoubtedly to a member of Soricini, the genera of other tribes (such as Blarinella, Mafia, Zelceina, Petenyia etc.) can be excluded. Default identification with the genus Sorex is, of course, not entirely supported for that the members of the genus of the corresponding size appearing prior to Middle Pleistocene (when the respective size was attained in the subgenus Sorex - cf. Horáček \& Ložek, 1988) were exclusively members of the subgenus Drepanosorex (MN17 praearaneus Kormos, 1934, Q1 margaritodon Kormos, 1934), which bear an indistinct and light orange teeth colouration not dark red as in the items under study. The full combination of the characters appearing in the respective fossils (including size and colouration of cusp enamel) can be found in another genus of Soricini, Deinsdorfia Heller, 1963. Also relative sharp incision at mesial margin of the first ridge cusp (particularly in the specimen figured in $\mathrm{Pl} .2 / 2$ ) and relatively inflated occlusal basin of the tooth (Pl. 2/1) seem to support that identification.

The genus was described from MN17 site of Deinsdorf and its separate status was confirmed by further studies including a monograph by Reumer (1984) who synonymized its nominotypical species franconica Heller, 1963 was later synonymized with hibbardi Sulimski 1962 described (as Sorex hibbardi) from MN15 site of Węże (see also Rzebik-Kowalska, 1990). Subsequently, six other species were described from various sites in Hungary, Poland and Greece ranging from MN14 (Podleśice site) to early MN17 (Deinsdorf site) or MN16. The exact species identification of our specimens is not possible though a broad measure of agreement is with both hibbardii/franconica and kordosi Reumer, 1984 (MN16 Csarnóta site) for which good information on incisor morphology is available (Reumer, 1984).

\section{Beremendia fissidens (Petenyi, 1864) (Pl. 2: 3-4)}

The enamel coat of the left M/1 and $\mathrm{M} / 2$ (apparently belonging to one and the same individual) provides a quite reliable morphological information: the teeth clearly show the characters distinguishing Beremedia fissidens, one of index fossils 


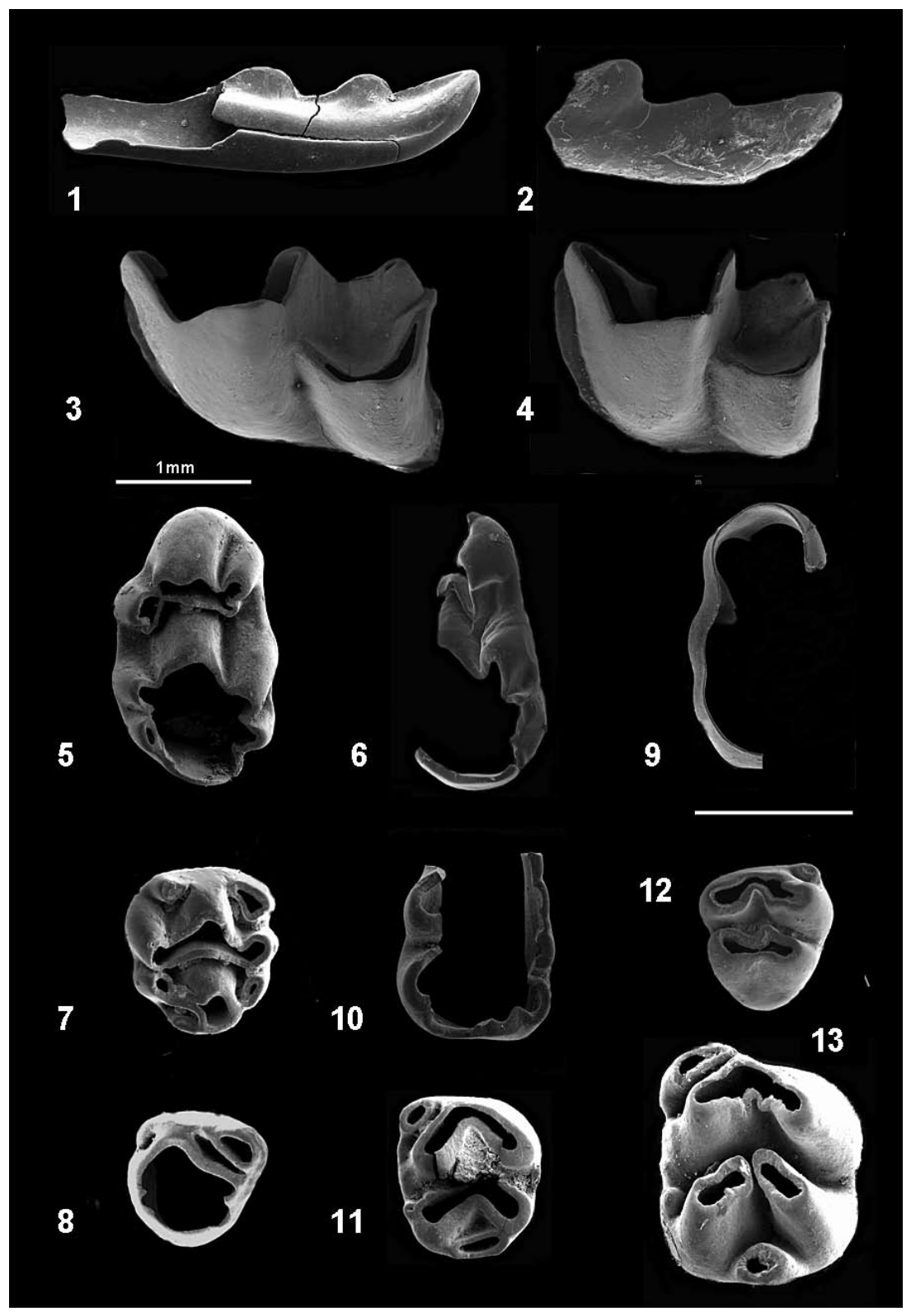

Plate 2: Soricidae and Muridae of the Črnotiče II site: 1 - Deinsdorfia sp. - left I/1; 2 - Deinsdorfia sp., right I/1; 3 - Beremendia fissidens (Petenyi, 1864), left $M / 1 ; 4$ - Beremendia fissidens (Petenyi, 1864), left M/2; 5 - Apodemus (Sylvaemus) cf. atavus Heller, 1936, left M1/;; 6 - Apodemus (Sylvaemus) cf. atavus Heller, 1936, left M1/; 7 - Apodemus (Sylvaemus) cf. atavus Heller, 1936, right M2/; 8 - Apodemus (Sylvaemus) cf. atavus Heller, 1936, right M3/; 9 - Apodemus (Sylvaemus) cf. atavus Heller, 1936, right M/1; 10 - Apodemus (Sylvaemus) cf. atavus Heller, 1936, right M/1; 11 - Apodemus (Sylvaemus) cf. atavus Heller, 1936, left M/2; 12 - Apodemus (Sylvaemus) cf. atavus Heller, 1936, right M/3;13 - Rhagapodemus cf. frequens Kretzoi, 1959, left M/2.

of the Pliocene shrew communities. It concerns their large size (M/1: L 2.40, tlL 0.80, tlW 1.40, M/2: L 1.98, tlL 0.5 , tlW 1.25), characteristically shaped entoconid, moderately developed labial cingulum or a dark red colouration in major crown tips. The teeth are at lower margin of the metric variation of the species, distinctly smaller than Blarinoides mariae Sulimski, 1962 (the species which also differs in proportions of $\mathrm{M} / 2$ and often in lighter colouration of enamel) though they are larger than Beremendia minor RzebikKowalska, 1976 the form reported from four MN14-MN16 localities.

Beremendia fissidens was euconstant element of the Pliocene mammalian communities from Spain, France and England to Poland, Ukraine, Romania, Croatia and Greece. Though its first appearance is reported even from late MN14 (Podleśice site) as a common species it appeared particularly in MN16 and MN17 (Rzebik-Kowalska in 1998 listed at least 30 sites of that age). It was regular but rare element even in the mid-European Q1 communities (as well as in Italy - Gliozzi et al., 1997) while during Q2 biozone (late Biharian) it was in most parts of its former range already extinct (van den Hoek et al., 2005)

\section{Glirulus sp. (Pl. 3: 1)}

Nearly complete fragment of a crown enamel of glirid tooth (M3/ d. or $\mathrm{P} 4 / \mathrm{d}$.) represents quite important item of the collection. The tooth is remarkable for its very small size (L $0.70 \times \mathrm{W} 0.82$ ) and besides of four main ridges (connected with a complete endoloph) it bears quite a distinct secondary ridge between them. The occlusal surface is relatively flat and not deflected as in extant genera Dryomys, Eliomys or Myomimus (including the smallest form Myomimus setzeri Rossolimo, 1976 to which it corresponds in size) which may come in account for biogeographic reasons (Kryštufek \& Vohralík, 2005). The above mentioned differences, which exclude co-identification of the fossil item with these extant taxa and the PlioPleistocene forms related to them (such as Dryomimus eliomyoides Kretzoi, 1959) fit quite well to the diagnostic characters of Glirulus pusillus, the form described as Amphidyromys pusillus Heller, 1936 from MN15/16 site of 


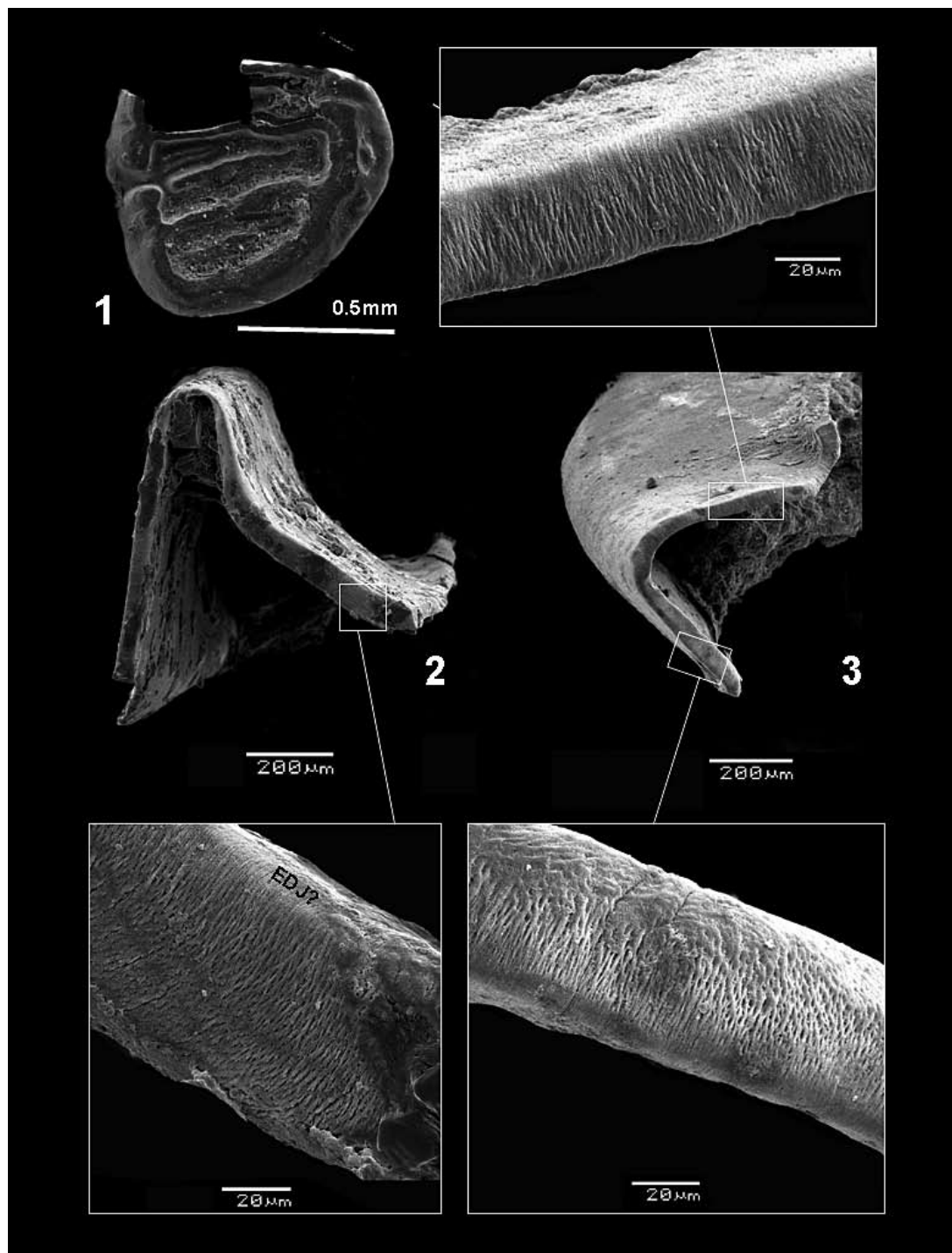

Plate 3: Gliridae and Arvicolidae from the Črnotiče II site: 1 - Glirulus sp., right M3/ or P4/; 2 - Arvicolidae g.sp. - Cseria gracilis/carnutina grade, ?left M1/; 3 - Arvicolidae g.sp. - Cseria gracilis carnutina grade.

Gundersheim. In Europe, the genus Glirulus (extant in Japan) to which pusillus was replaced by Kowalski (1963) was continuously represented from MN3 with several species throughout Miocene (cf. Kowalski, 1997, 2001), while its diversity got restricted to a sole species, pusillus, in MN15 to MN17 (Daams \& de Bruijn, 1995). In Europe, this species probably locally survived up to the earliest stage of Q1 zone of the Early Pleistocene (Valerots, Żabia sites). In Italy Glirulus pusillus is recorded from MN15 Arondelli-Triversa and Glirulus sp. from Q1 Monte Peglia (Kotsakis, 2003). In the MN15,16 and early MN17 communities of central and southern Europe Glirulus pusillus appears as nearly a constant element ( $c f$. its records in sites of Gundersheim, Ivanovce, Frechen, Schernfeld,
Osztramos 7, Kielniki 1, a.o.). Last but not least we are obliged to note that despite good correspondence between the fossil item and Glirulus pusillus in the essential characters of the genus, the fossil items differ markedly in proportion and shape of the tooth and the differences seem to fall beyond the variation range of pusillus. Alternatively, the tooth can be looked upon as P4/, eventually (then the differences from other species of the genus would be even larger). Unfortunately, with just a single fragmentary item, there is a little chance to comprehend the actual meaning of these differences properly and it would be much beyond scope of this report to discuss that topic in details.

\section{Apodemus (Sylvaemus) cf. atavus} Heller, 1936 (Pl. 2/5-13, Pl. 4/1)

The teeth remains of wood mouse are the best preserved fossils in both studies sites. They belong to medium-sized forms of the subgenus Sylvaemus and could be co-identified even with the most widespread extant species Apodemus sylvaticus, eventually. Nevertheless, the items from Črnotiče II exceed the variation range of the recent species at least in two respects: in appearance of distal cingulum on $\mathrm{M} 1 /$ and $\mathrm{M} 2 /$ and posterior accessory cusp (sensu van Dam, 1997) on $M / 2$. Both the characters, considered plesiomorphic states in murids, distinguish a fossil species Apodemus atavus Heller, 1936, described from MN16 Gundersheim site, and considered to be an ancestor of the recent European representatives of the subgenus Sylvaemus (Rietschel \& Storch, 1974; Kowalski, 2001). In the state of both the characters the specimens under study seem to exhibit an intermediate position between the typical MN15 atavus (including its topotypes $-c f$. Storch \& Fejfar, 1989; Fejfar \& Storch, $1990)$ and the recent taxon. Of course, a real taxonomic meaning of similar differences could be estimated only after detailed comparative studies on variation dynamics of the respective characters for which the available material is apparently too scarce. Moreover, in regard to the recent situation of the genus in the SE Europe and E- 
Mediterranean (extensive genotypic diversification and considerable overlap among all the species in morphometric characters), the attempts to resolve the taxonomic status of fragmentary fossil samples seem to be only little promising. In any case, in metrical characters the teeth under study are at the lower variation range of $A$. sylvaticus but seem to fall well in the range the respective species: Račiška pečina M/1 (P14/1): 1.67x1.5 mm, Črnotiče M1/ (Pl 2/5): 1.75x1.12 mm, M1/ (Pl2/6) L 1.73 mm, M2/ (Pl2/7): $1.13 \times 1.06 \mathrm{~mm}, \mathrm{M} 3 /(\mathrm{Pl} / 8): 0.85 \times 0.86 \mathrm{~mm}, \mathrm{M} / 1$ (Pl2/9): L $1.75 \mathrm{~mm},(\mathrm{pl} / 10): \mathrm{W} 1.00 \mathrm{~mm}, \mathrm{M} / 2$ (Pl 2/11): 1.20x $1.02 \mathrm{~mm}, \mathrm{M} / 3$ (Pl 2/12): 0.97x0.86.

\section{Rhagapodemus cf. frequens Kretzoi, 1959 (Pl. 2 /13)}

A single $M / 2$ nearly unaffected by abrasion is characterized by very large dimensions $(1.72 \times 1.35 \mathrm{~mm})$, extreme degree of hypsodonty, nearly completely separated hypoconid and entoconid, well developed lateral anteroconid and postcingulid while labial cingular cusps are quite minute and arranged in a shallow cingular crestlike ridge at the base of the crown. In all these characters the tooth exceeds variation ranges in all European extant species of Apodemus (including epimelas and mystacinus, i.e. the larges extant $\mathrm{W}$-Palearctic forms of the genus) but corresponds well to the diagnostic characters of Pliocene genus Rhagapodemus Kretzoi, 1959.

At the same time, the state of the respective characters in the specimen seems to exhibit a more derived conditions than Turolian Rhagapodemus primaevus (Hugeney et Mein, 1965) or early Ruscinian R. hautimagnensis Mein et Michaux, 1970 (comp. also Popov, 2004), the other species of that age such as R. ballesioi Mein et Michaux, 1970 or R. debruijni (Kotlia, 1992) differ even more (they are distinctly smaller, lack the posteriod cingular cusps etc. - comp. Fejfar \& Storch 1990; Kotlia et al., 1998; Popov, 2004). Perhaps the best agreement is thus with the nominotypical species Rhagapodemus frequens Kretzoi, 1959 described from the MN15 site of Csarnóta and later found in more sites of a similar age (MN 15 Węże, Gundersheim 4) and with even a more derived form, distinguished at the subspecific level as $R$. frequens athensis De Bruijn et van der Meulen, 1975 reported also from the early Pleistocene of Greece (locality Tourkoubounia 1: De Bruijn \& van der Meulen, 1975). The actual stratigraphic position of Tourkoubounia 1 in terms of MN zones is MN16 (Doukas, 2005). The genus Rhagapodemus is further reported from the early and middle Pleistocene of Sardinia. Of course, particularly under island situations, a parallel evolution of the Rhagapodemus phenotypes not related to the Miocene and Pliocene mainland forms could also come in account, similarly as it was suggested by Kotlia et al. (1998) for Indian R. debruijni (Kotlia, 1992).
Arvicolidae (see Pl. 3/2-3, Pl. 4/ 2-4 for the best pr served items)

In general, Arvicolidae is the group of the highest importance for the biostratigraphic analyses of the late Cenozoic terrestrial deposits for well marked gradual anagenetic trends, parallel in different clades, extensive cladogetic diversity and predominant representation in the mammalian communities of that period (Fejfar et al., 1997). Correspondingly, also in the present samples the remains of arvicolids compose an essential part of the total material. Unfortunately, not one complete tooth is available and a vast majority of the material consists of isolated, broken and corroded enamel fragments, as a rule representing just single molar synclinales. The most complete specimens are figured on Plates 3 and 4 . In both localities, any rootless form absents, and no one piece shows a trace of dental cementum in the molar synclinales.

The molar fragments from the Račiška pečina exhibit a considerably high degree of hypsodonty, some of them are with deep and narrow synclinales typical for Lagurini. The enamel microstructure revealed by the SEM analyses suggest that at least two different forms are present in the Račiška pečina: one exhibiting the pattern typical for advanced lagurine voles (dense radial enamel alternated with a thick layer of lamellar enamel which prisms are distinctly heavier than the prisms of radial enamel, Pl. 4/3), the other shows the pattern with less distinct differences between radial and lamellar enamel (Pl. 4/2) corresponding to the situation in the genera Myodes or advanced forms of Mimomys (Koenigswald, 1980; Fejfar \& Heinrich, 1982).

In contrast, all fragments available from Črnotiče II site show rather plesiomorphic constitution particularly in clearly lower degree of molar hypsodonty. Their Schmelzmuster is quite different from that in the Račiška pečina, first in that it bears the same enamel pattern both in mesial and distal walls of a tooth (Pl. 3/2,3), second that the lamellar enamel is not developed and only radial enamel is present with faint anastomozing near the EDJ instead of prism decusation. Such constitution is apparently quite plesiomorphic and it was recorded in ancient member of Mimomys/Cseria lineages such as Cseria carnutina Rabeder 1981 or Mimomys (Cseria s.str) gracilis, i.e. the taxa typical of the MN15 stage of arvicolid radiation (Rabeder, 1981; Fejfar \& Heinrich, 1982). In any case, such enamel arrangement is undoubtedly connected with rather archaic grade of arvicolid dental evolution and probably does not occur in the European forms since the early MN17.

\section{BIOSTRATIGRAPHIC CONSIDERATIONS}

For a proper biostratigraphic analysis, the available material is unfortunately too scarce and too fragmentary. 


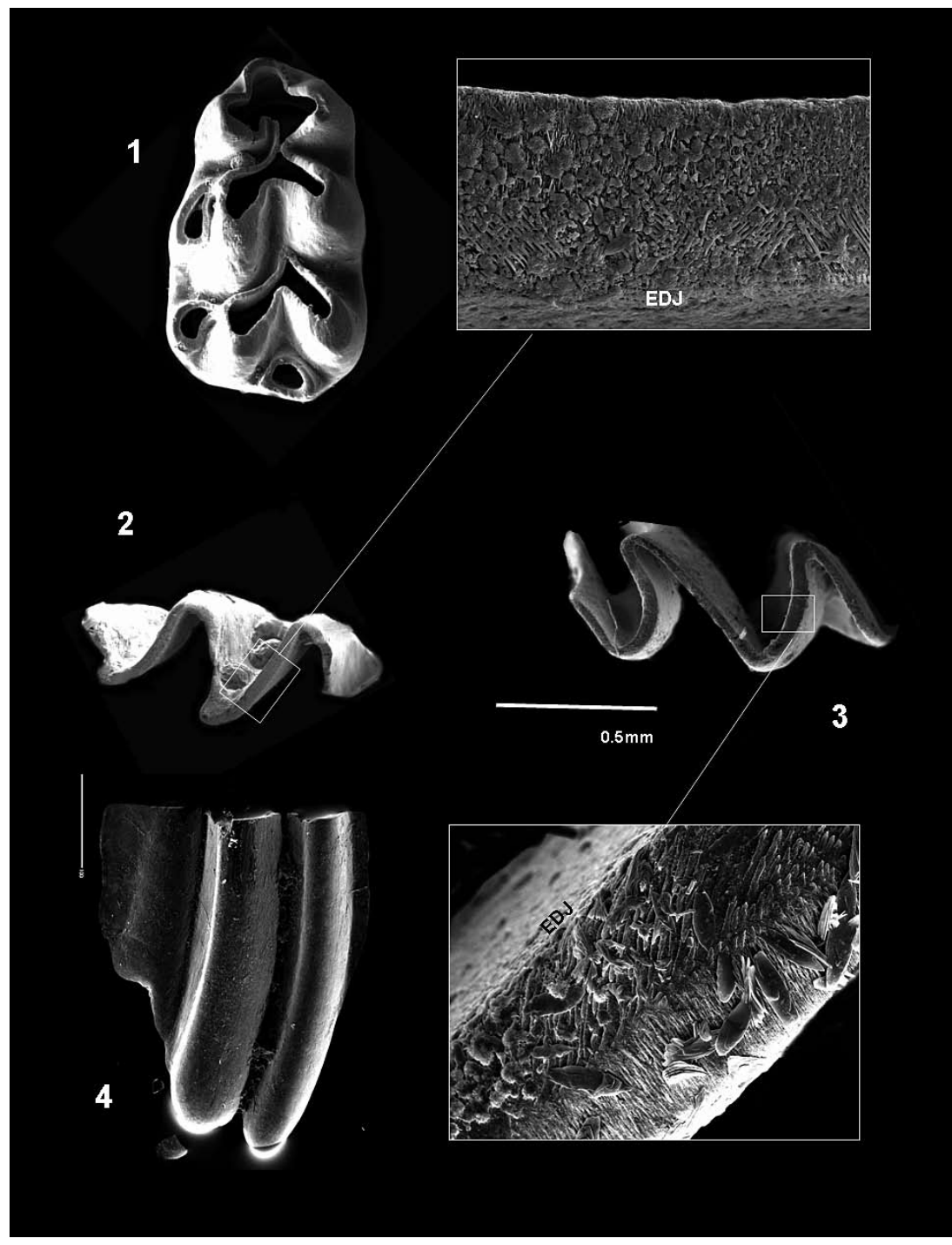

Plate 4: Mammalian fossils from the Račiška pečina: 1-Apodemus (Sylvaemus) cf. atavus Heller, 1936, left M/1; 2 - Arvicolidae g.sp. indet., fragment of a lingual? wall of $M / 1, c f$. Borsodia spp.; 3 - Arvicolidae g.sp. indet., fragment of a palatal wall of an upper molar (M1/ or M2/), cf. Mimomys (Cseria) sp.; 4 - Arvicolidae, g.sp. indet., lingual wall of the right $M 3 /$, cf. Borsodia sp.

Nevertheless, it provides a certain information enabling to draw hypothesis on possible maximum and minimum age of the communities. The absence of rootless molars in arvicolid material, both in the Črnotiče II site and the Račiška pečina, suggests that the communities do not come from the Quaternary period namely because since beginning of the Q1 the communities of small ground mammals are characterized by total predominance of rootless voles (particularly Microtus s.l. and Lagurus s.l., etc.) and its seems greatly improbable that no one of 48 molar fragments obtained from studied sites would exhibit such a state. In Lagurini, the rooted forms, arranged in genus Borsodia (to which we tentatively allocate some items from the Račiška pečina) soon at the very beginning of Q1 disappeared in account of their rootless descendants.

At least for above-mentioned reasons, we propose $\mathrm{MN} 17 / \mathrm{Q} 1$ boundary as the possible minimum age both for the Črnotiče II site and Račiška pečina. In both sites, the faunal assemblages are of the Pliocene age (note the predominance of arvicolids and absence of any element suggesting strictly the Miocene age as well as the data on stratigraphic distribution of the recorded taxa - Tab. 1). The possible maximum age for the Račiška pečina can be tentatively placed to MN16 or early MN17 particularly due to the advanced degree of hypsodonty in arvicolid molars, the correspondence of some items to Borsodia (the genus representing an index fossil of MN17) or to relatively advanced $\mathrm{Mi}$ momys spp. (a grade corresponding to e.g., jota/pitymyoides sensu Rabeder, 1981). However for Črnotiče II site, the grade of arvicolid molar development would suggest a rather earlier age. Correspondingly, also all other forms identified there ( $D e$ insdorfia, Beremendia, Glirulus aff. pusillus, Rhagapodemus frequens and Apodemus cf. atavus) are typical more for MN15 or MN 16 than for MN17. The possible maximum age corresponding to the stratigraphic span of these taxa would then be even around MN14/MN15 boundary. Considering the fragmentary faunal list from the Črnotiče II site, as a relevant community sample, we could find close resemblance to the fauna composition of the Ruscinian or Csarnótan assemblages such as in Gundersheim or Csarnóta 2 sites.

Summarizing the above-mentioned arguments, an intuitive consensual biostratigraphic allocation of the assemblages under study would be: (i) middle to late MN17 (ca 1.8-2.4 Ma) for the Račiška pečina and (ii) MN15MN16 (ca. 3.0-4.1 Ma) for the Črnotiče II site.

The dating of the latter site is particullary important because the source deposits are directly realted to termination of active freatic regime. 
Table 1: Stratigraphical distribution of some taxa which come in account in context of the forms recorded in Řačiška pečina and Črnotiče II (in bold). Minimum number of localities for shrews (after Rzebik-Kowalska 1998, slightly supplemented) or presence/absence (+/-) for rodents (mostly after Kowalski 2001). For definitions and chronological setting of MN zones see Mein 1990, for Q zones see Horáček \& Ložek (1988).

\begin{tabular}{|c|c|c|c|c|c|c|c|}
\hline \multirow[b]{2}{*}{ sp. / biozones (MN/Q) } & \multicolumn{4}{|c|}{ Pliocene } & \multicolumn{3}{|c|}{ Quaternary } \\
\hline & 14 & 15 & 16 & 17 & 1 & 2 & $3-R$ \\
\hline Beremendia fissidens & 3 & 11 & 32 & 20 & 44 & 6 & - \\
\hline Beremendia minor & 1 & 1 & 3 & - & - & - & - \\
\hline Blarinoides mariae & 5 & 9 & 9 & 5 & - & - & - \\
\hline Blarinoides sp. & 3 & 2 & 1 & - & - & - & - \\
\hline Deinsdorfia fallax & - & 1 & - & - & - & - & - \\
\hline Deinsdorfia hibbardi & 1 & 3 & 9 & 3 & 1 & - & - \\
\hline Deinsdorfia insperata & 1 & - & - & - & - & - & - \\
\hline Deinsdorfia janossyi & 1 & - & - & - & - & - & - \\
\hline Deinsdorfia kerkhoffi & 1 & - & - & - & - & - & - \\
\hline Deinsdorfia kordosi & - & 5 & 1 & - & - & - & - \\
\hline Deinsdofia reumeri & 1 & - & - & - & - & - & - \\
\hline Glirulus spp. & + & - & - & - & - & - & - \\
\hline Glirulus pusillus & - & + & + & + & $(+)$ & - & - \\
\hline Glirulus sp. & - & - & - & - & + & - & - \\
\hline Apodemus dominans & - & + & + & (?) & $(?)$ & - & - \\
\hline Apodemus atavus & - & + & + & - & - & - & - \\
\hline Apodemus cf. sylvaticus & - & - & - & + & + & + & + \\
\hline Rhagapodemus primaevius & $?$ & - & - & - & - & - & - \\
\hline Rhagapodemus hautimagnesis & + & + & - & - & - & - & - \\
\hline Rhagapodemus vanderweerdi & + & - & - & - & - & - & - \\
\hline Rhagapodemus frequens & - & + & + & - & - & - & - \\
\hline Rhagapodemus (frequens) athensis & - & - & + & - & - & - & - \\
\hline Myodes & - & - & + & + & + & + & + \\
\hline Borsodia & - & - & $(+)$ & + & $(+)$ & - & - \\
\hline Lagurus s.l. & - & - & - & - & + & + & + \\
\hline Cseria gracilis/minor/csarnutina grade & - & + & + & - & - & - & - \\
\hline Mimomys pitymyoides/pusillus grade & - & - & $(+)$ & + & $(+)$ & - & - \\
\hline Microtus s.l. & - & - & - & - & + & + & + \\
\hline
\end{tabular}

\section{CONCLUSIONS}

Although the fossil record obtained from cave sediments of the Črnotiče II site and Račiška pečina is rather poor, both in its taxonomic structure and preservation it provided a valuable biostratigraphic information. The data enabled to specify the supposed time frame for dating of respective cave deposits dated by the previous interpretation of paleomagnetic (magnetostratigraphic) data. Paleontological data proved suggested MN15-16 mammalian biozone as the most probable date (about 3.0-4.1 $\mathrm{Ma}$ ). Aguilar et al. (2002) placed the MN15/16 boundary in the period between chron C2A2.1n (based on MN16 Seynes) and C2r.2r (based on MN15 Sete), i.e. at ca 2.5-
3.0 Ma, although Lindsay et al. (1997) or Lindsay (2001) proposed MN15/16 boundary position rather at the base of Gauss Chron.

The arrangements of obtained magnetozones in the Črnotiče II site were originally interpreted as older than $1.770 \mathrm{Ma}$, most probably belonging to the Gauss Chron (2.581-3.580 Ma) or the normal subchrons within the Gilbert Chron (4.180-5.230 Ma). The long normal paleomagnetic polarity zone in the lower segment of the fill therefore corresponds to basal normal polarized subchron C2An.3n (3.330-3.580 Ma) within the Gauss Chron and the normal polarized upper segment can be 
compared to some of higher normal subchrons of the Gauss Chron (C2An.1n subchron $=2.581-3.040 \mathrm{Ma}$ or C2An.2n subchron $=3.110-3.220 \mathrm{Ma})$. The combination of paleontological and paleomagnetic data indicates, that the fauna cannot be older than about $3.6 \mathrm{Ma}$, due to reverse polarized magnetozone at top of Gilbert Chron terminating at $4.180 \mathrm{Ma}$. This level represents approximately also the base of the MN15 mammalian biozone.

In the Račiška pečina, the boundary of normal and reverse polarized magnetozone within the layer with fauna (Fig. 3) is identified with the bottom of C2n Olduvai subchron (1.770-1.950 Ma). The geometry of obtained magnetozones is deformed as compared with subchrons on the GPTS due to numerous principal breaks in deposition in the lower part of the profile. Break can last more than $250 \mathrm{ka}$. Therefore, we correlate this part with the lower part of the Matuyama Chron (2.150-2.581 Ma) and individual subchrons of the Gauss Chron (2.581-3.58 $\mathrm{Ma})$. The profile above Olduvai subchron records short part of Matuyama Chron (some of reverse polarized subchrons C1r.3r, C1r.2r, or C1r.1r within the time span of 1.770-0.780 Ma) and Brunhes Chron (C1n; younger than $0.780 \mathrm{Ma}$ )

For the first time, the combination of vertebrate fossil records and magnetostratigraphy proved expected antiquity of the cave fossilization in the region of the Classical Karst. A good agreement of biostratigraphic and magnetostratigraphic inferences suggests autochtonous synsedimentary origin of the faunal remains and sediments and supports strongly expected relevance of the dating effort and its applicability in karstogenetic reconstructions. Further step in that direction will be published in another place. Worth mentioning is that the important paleotectonic movements recently interpreted in Dinarides (Ilić \& Neubauer, 2005) and Southern Alps (Neubauer, 2007), which could be related to the uplift in the Classical Karst and rearrangements of its hydrological systems resulting in increased fossilisation rate, correspond in age to MN15 zone. The fossilization during MN15-MN17 finished one of important older phases of speleogenesis in the region.

\section{ACKNOWLEDGEMENT}

The study was supported by the Grant Agency of the Academy of Sciences of the Czech Republic Nos. GAAVČR IAA300130701 Paleomagnetic research of karst sediments: paleotectonic and geomorphologic implications (2007-2010), and GAAVČR IAA3013201 Magnetomineralogic and magnetostratigraphic research of cave and fluvial sediments in the Central European region (20022005), and by the Institutional Research Plan of the GLI AS CR, v.v.i. No. CEZ AV0Z30130516 (to PP, PB). Partial support was also obtained from grants of the Grant Agency of the Czech Republic No. GACR 206/05/2334, and Ministry of Education, Sport and Youths of the Czech Republic No. 0021620828 (to IH). The research was performed within the frame of research programs financed by Ministry of Science of Slovenia and Slovenian Research Agency No.: P6-0119-0618 and P0-0119 Karst Research, and projects Nos.: J6-3035-0618-01 Origin and development of karst caves, and J6-6345-0618-04 Development and function of caves in different speleological settings (to AM, NZH). The research represents also the results of the Czech - Slovenian bilateral science and technology cooperation programs Nos.: ME
251(1998) Research of karst sediments on the example of the Classical Karst, Slovenia (1998-1999), No. 2001/009 Evolution of karst and caves based on study of cave fills, Slovenia (2001-2003), 28-2003-04 Reconstruction of speleogenesis and karstogenesis from the study of cave fill, Slovenia (2003-2004), 13-2005-06 Paleomagnetic studies of sediments in karst areas of Slovenia: implication for paleotectonic reconstructions (2005-2006), and 9-06-19 Paleomagnetism of sediments in karst areas of Slovenia (2007-2008) covered by Ministry of Science of Slovenia and Ministry of Education, Sport and Youths of the Czech Republic (to AM, NZH, PP, PB).

We acknowledge the field assistance of Mr. Franjo Drole, Mr. Jure Hajna, Dr. Jaroslav Kadlec, Mr. Petr Schnabl and Mr. Stanislav Šlechta, and the help of Mrs. Jana Rajlichová (Institute of Geology AS CR, v.v.i., Praha) and Mr. Jure Hajna (Karst Research Institute, ZRC SAZU, Postojna), who drew some of the figures. We are particularly obliged to Jean-Pierre Aguilar, Jacques Michaux, Bernard Sigé and Dragica Turnšek who carefully reviewed the manuscript and their suggestions improved it in an essential way. 


\section{REFERENCES}

Absolon, K. \& S. Hrabě, 1930: Über einen neuen Süsswasser-Polychaten aus den Höhlengewässern der Herzegowina.- Zoologisher Anzeiger, 88, 9-10, 259264, Jena.

Aguilar, J.-P., Crochet, J.-Y., Hebrard, O., Le Strat, P., Michaux, J., Pedra, S. \& B.Sigé, 2002: Les micromammiferes de Mas Rembault 2, gisement karstique du Pliocène supérieur du sud de la France, âge, paléoclimat, géodynamique.- Géologie de la France, 4, 17-37.

Aguilar, J.-P., Crochet, J.-Y., Krivic K., Marandat, B., Michaux, J., Mihevc, A., Sigé, B. \& S. Šebela, 1998: Pleistocene small mammals from karstic fillings of Slovenia - Preliminary results.- Acta Carsologica, 27/2, 141-150, Ljubljana.

Aguirre, E. \& G. Pasini, 1985: The Pliocene-Pleistocene boundary.- Episodes, 8, 116-120, Ottawa.

Bosák, P., 2002: Karst processes from the beginning to the end: how can they be dated?- In: Gabrovšek, F. (Ed.): Evolution of Karst: From Prekarst to Cessation, Carsologica, Založba ZRC, Postojna-Ljubljana, 191-223.

Bosák, P., Pruner, P. \& N. Zupan Hajna, 1998: Paleomagnetic research of cave sediments in SW Slovenia.Acta Carsologica, 27/2, 3, 151-179, Ljubljana.

Bosák, P., Mihevc, A., Pruner, P., Melka, K., Venhodová, D. \& A. Langrová, 1999: Cave fill in the Črnotiče Quarry, SW Slovenia: Palaeomagnetic, mineralogical and geochemical study.- Acta Carsologica, 28/2, 2, 15-39, Ljubljana.

Bosák, P., Pruner, P., Mihevc, A. \& N. Zupan Hajna, 2000a: Magnetostratigraphy and unconformities in cave sediments: case study from the Classical Karst, SW Slovenia.- Geologos, 5, 13-30, Poznań.

Bosák, P., Knez, M., Otrubová, D., Pruner, P., Slabe, T. \& D. Venhodová, 2000b: Palaeomagnetic Research of Fossil Cave in the Highway Construction at Kozina, SW Slovenia.- Acta Carsologica, 29/2, 1, 15-33, Ljubljana.

Bosák, P., Pruner, P. \& J. Kadlec, 2003: Magnetostratigraphy of cave sediments: application and limits. Studia Geophysica et Geodaetica, 47, 2, 301-330, Praha.

Bosák, P., Mihevc, A. \& P. Pruner P., 2004a: Geomorphological evolution of the Podgora Karst, SW Slowenia: Contribution of magnetostratigraphic research of the Črnotiče II site with Marifugia sp.- Acta Carsologica, 33, 1, 12, 175-204. Ljubljana.
Bosák, P., Pruner, P., Mihevc, A., Zupan Hajna, N., Horáček, J., Kadlec, J., Man, O. \& P. Schnabl, 2004b: Račiška pečina.- $12^{\text {th }}$ International Karstological School, Classical Karst - Dating of Cave Sediments, Postojna. Guide booklet for the excursions and abstracts of presentations, 23-27, Postojna.

Brodar, S., 1952: Prispevek k stratigrafiji kraških jam Pivške kotline, posebej Parske golobine.- Geografski vestnik, 24, 43-76, Ljubljana.

Brodar, S., 1958: Črni kal, nova paleolitska postaja v Slovenskem Primorju.- Razprave 4.razreda, 4, 271-363, Ljubljana.

Brodar, S., 1966: Pleistocenski sedimenti in paleolitska najdišča v Postojnski jami.- Acta carsologica, 4, 57138, Ljubljana.

Brodar, S., 1970: Paleolitske najdbe v jami Risovec pri Postojni.- Acta carsologica, 5, 273-300, Ljubljana.

Bruijn, H. De \& A.J. van der Meulen, 1975: The early Pleistocene Rodents from Tourkoubounia-1 (Athens, Greece). I.- Koninklijke Nederlandse Akademie van Wetenschappen, Proceedings B, 78: 314-338.

Cande, S.C. \& D.V. Kent, 1995: Revised calibration of the geomagnetic polarity timescale for the Late Cretaceous and Cenozoic. - Journal of Geophysical Research, 100, B4, 6093-6095, Washington.

Colman, S.M. \& K.L. Pierce, 2000: Classification of Quaternary geochronologic methods.- In: Noller, J.S., J.M. Sowers \& W.R. Lettis (Eds.): Quaternary Geochronology. Methods and Applications, American Geophysical Union, 2-5, Washington.

Daams, R. \& H. de Bruijn., 1995: A classification of the Gliridae (Rodentia) on the basis of dental morphology.- Hystrix, 6, 3-50, Rome.

Dam, J.A. van, 1997: The small mammals from the Upper Miocene of the Teruel-Alfambra region (Spain): palaeobiology and paleoclimatic reconstructions.Geologica Ultraiectina, 156, 1-204. Utrecht.

Doukas, C.S., 2005: Greece.- In: Hoek Ostende, L.W. van den, Doukas, C.S. \& J.W.F. Reumer, (Eds.): The Fossil Record of the Eurasian Neogene Insectivores (Erinacomorpha, Soricomorpha, Mammalia). Part I. Scripta Geologica, Special Issue, 5, 99-112, Leiden.

Fejfar, O. \& W.-D. Heinrich, 1982: Zur Evolution von Mimomys (Rodentia, Mammalia) in Csarnótanum und Villafranchium Europas.- Eclogae Geologicae Helvetiae, 72, 779-793, Basel.

Fejfar, O., Heinrich, W.-D., Pevzner, M.A. \& E.A. Vangenheim, 1997: Late Cenozoic sequence of mammalian sites in Eurasia: an updated correlation.- Palaeogeography, Palaeoclimatology, Palaeoecology, 133, 259-288, Amsterdam. 
Fejfar, O. \& G. Storch, 1990: Eine pliozäne (ober-ruscinische) Kleinsäugerfauna aus Gundersheim, Rheinhessen - 1. Negetiere: Mammalia, Rodentia.- Senckebergiana lethaea, 71, 139-184, Frankfurt a. M.

Fisher R., 1953: Dispersion on a sphere.- Proceedings of the Royal Society, A 217, 295-305, London.

Ford, D. \& R. Gospodarič, 1989: U series dating studies of Ursus spelaeus deposits in Križna jama, Slovenia.- Acta carsologica, 18, 39-51, Ljubljana.

Franke, H. \& M. Geyh, 1971: 14C - datierungen von Kalksinter aus slowenischen Höhlen.- Der Aufschluss, $22,7-8,235-237$.

Gliozzi, E., Abbazzi, L., Argenti, P., Azzaroli, A., Caloi, L., Barbato, L.C., Di Stefano, G., Esu, D., Ficcarelli, G., Girotti, O., Kotsakis, T., Masini, F., Mazza, P., Mezzabotta, C., Palombo, M.R., Petronio, C., Rook, L., Sala, B., Sardella, R., Zanalda, E. \& D. Torre, 1997: Biochronology of selected mammals, molluscs and ostracods from the Middle Pliocene to the Late Pleistocene of Italy. The state of the art.- Rivista Italiana di Paleontologia e Stratigrafia, 10, 3, 369387, Milano.Gospodarič, R., 1972: Prvi podatki o absolutni starosti sige $\mathrm{v}$ Postojnski jami na podlagi 14C.- Naše jame, 13, 91-98, Ljubljana.

Gospodarič, R., 1974: Fluvialni sedimenti v Križni jami.Acta carsologica, 6, 327-366, Ljubljana.

Gospodarič, R., 1976: Razvoj jam med Pivško kotlino in Planinskim poljem v kvartarju.- Acta carsologica, 7, 5-139, Ljubljana.

Gospodarič, R. 1977: Generacije sige v nekaterih kraških jamah.- Geografija krasa, Poročila 1977, 1-31, IZRK SAZU, Postojna.

Gospodarič, R. 1981: Generacije sig v klasičnem krasu Slovenije.- Acta carsologica, 18, 39-51, Ljubljana.

Gospodarič, R. 1984: Jamski sedimenti in speleogeneza Škocjanskih jam.- Acta carsologica, 12 (1983), 27 48, Ljubljana.

Gospodarič, R. 1985: O speleogenezi Divaške jame in Trhlovce.- Acta carsologica, 8 (1984), 5-36, Ljubljana.

Gospodarič, R. 1988: Paleoclimatic record of cave sediments from Postojna Karst.- Annales de laq Société géologique de Belgique, 111, 91-95, Liège.

Heller, F., 1936: Eine oberpliocäne Wirbeltierfauna aus Rheinhessen.- Neues Jahrbuch der Mineralogie, Geologie und Paläontologie, Beilage-Band 63, Abt. B, 76, 99-160, Stuttgart.

Hoek Ostende, L.W. van den, Doukas, C.S. \& J.W.F. Reumer, Eds., 2005: The Fossil Record of the Eurasian Neogene Insectivores (Erinacomorpha, Soricomorpha, Mammalia). Part I.- Scripta Geologica, Special Issue, 5. Leiden.
Horáček, I. \& V. Ložek, 1988: Palaeozoology and the mid-European Quaternary past: scope of the approach and selected results.- Rozpravy ČSAV, řada matematických a př́rodních věd, 94, 1-106, Praha.

Ikeya, M., Miki, T. \& R. Gospodarič, 1983: ESR Dating of Postojna Cave Stalactite.- Acta carsologica, 11(1982), 117-130, Ljubljana.

Ilić A. \& F. Neubauer, 2005: Tertiary to recent oblique convergence and wrenching of the Central Dinarides: Constraints from a palaeostress study.- Tectonophysics, 410, 465-484, Amsterdam.

Kirschvink, J.L., 1980: The least-squares line and plane and the analysis of palaeomagnetic data.- Geophysical Journal of the Royal Astronomical Soc., 62, 699718 , Oxford.

Koenigswald, W. von, 1980: Schmelzstruktur und Morphologie in den Molaren der Arvicolidae (Rodentia).- Abhandlungen der senckenbergisches naturforschung Gesselschaft, 536, 1-129, Frankfurt a. M.

Kotlia, B.S., Storch, G. \& T. Dahlmann, 1998: Rhagapodemus debruijni from the Pliocene of Kashmir Basin: First record of Rhagapodemus from India (Mammalia: Rodentia).- Senckenbergiana lethaea, 78: 213-216.

Kotsakis, T., 2003: Fossil glirids of Italy: the state of the art.- Coloquios de Palentologia, Vol. Ext. 1, 335343, Barcelona.

Kowalski, K., 1963: The Pliocene and Pleistocene Gliridae (Mammalia, Rodenia) from Poland.- Acta zoologica Cracoviensis, 8, 533-567, Kraków.

Kowalski, K., 1997: Gliridae (Mammalia: Rodentia) from the Miocene of Belchatów in Poland.- Acta zoolologica Cracoviensis, 40, 173-198, Kraków.

Kowalski, K., 2001: Pleistocene rodents of Europe.- Folia Quaternaria, 72, 3-389, Kraków.

Kranjc, A., 1997: Introduction. In: A. Kranjc et al. (Eds): Kras. Slovene Classical Karst.- Znanstvenoraziskovni center SAZU, Inštitut za raziskovanje krasa, p. 11-17, Ljubljana.

Kryštufek, B. \& V. Vohralík, 2005: Mammals of Turky and Cyprus. Rodentia I: Sciuridae, Dipodidae, Gliridae, Arvicolinae.- Založba Annales, 292 pp, Koper.

Lindsay, E., 2001: Asynchrony in mammalian biochronology.- Lynx, N.S. 32, 201-214, Praha.

Lindsay, E., Opdyke, N.D. \& O. Fejfar, 1997: Correlation of selected ate Cenozoic European mammal fauna with the magnetic polarity time scale.- Palaeogeography, Palaeoclimatology, Palaeoecology, 133, $205-$ 226, Amsterdam.

Mein, P., 1990: Updating of MN zones.- In: Lindsay, E.H., Fahlbush V. \& P. Mein (Eds.): European Neogene mammal chronology, 73-90, Plenum Press, New York.

Mihevc, A., 1996: Brezstropa jama pri Povirju.- Naše jame, 38, 92-101, Ljubljana. 
Mihevc, A., 2000: Fosilne cevke iz brezstrope jame - verjetno najstarejši ostanki jamskego cevkarja Marifugia (Annelida: Polychaeta).- Acta Carsologica, 29/2, 261-270. Ljubljana.

Mihevc, A., 2001: Speleogeneza Divaškega krasa.- Zbirka ZRC, 27, 1-180, Ljubljana.

Mihevc, A., 2003: Sledovi jamskega medveda v Račiški pečini.- Naše jame, 45, 48-55, Ljubljana.

Mihevc, A., 2004: The unroofed Cave Ulica and Ulica pečina Cave.- 12th International Karstological School, Classical Karst - Dating of Cave Sediments, Postojna. Guide booklet for the excursions and abstracts of presentations, 27, Postojna.

Mihevc, A., 2007: The age of karst relief in West Slovenia.- Acta Carsologica, 36/1, 35-44, Ljubljana.

Mihevc, A., Bosák, P., Pruner, P. \& B. Vokal, 2002: Fosilni ostanki jamske živali Marifugica cavatica v brezstropi jami v kamnolomu Črnotiče v zahodni Slovenii.Geologija, 45/2, 471-474, Ljubljana.

Mihevc, A. \& Lauritzen, S.E., 1997: Absolute datations of speleothems and its speleomorphological significance from Divaška jama and Jazbina caves; Kras plateau, Slovenia.- Proceedings of the 12th International Congress of Speleology, 1997, Switzerland, 1 Symposium 7 Physical Speleology \& Symposium 8 Karst Geomorphology, 57-59, Speleo Projects, Basel.

Mihevc, A., Sket, B., Pruner, P. \& P. Bosák, 2001: Fossil remains of a cave tube worm (Polychaeta: Serpulidae) in an ancient cave in Slovenia.- Proc., 13th International Speleological Congress, 4th Speleological Congress of Latin America and the Carribean, 26th Brazilian Congress of Speleology, Brasilia, July 15-22, 2001, 2: 20-24, Brasilia.

Neubauer F., 2007: Neogene to Recent Motion of Adria, formation of the Friuli orocline, and deformation of Eastern Alps and northeastern Dinarides.- Geophysical Research Abstracts, 9, 06232 (SRef-ID: 1607-7962/gra/EGU2007-A-06323).

Ogg, J., 2007: Request for IUGS Ratification to Establish the Quaternary as a System/Period of the Cenozoic and revise the associated base of the Pleistocene Series.- Unpubl. letter, International Commission on Stratigraphy, IUCN, 21 pp., Oslo.

Otoničar, B., 2007: Upper Cretaceous to Paleogene forbulge unconformity associated with foreland basin evolution (Kras, Matarsko podolje and Istria; SW Slovenia and NW Croatia).- Acta Carsologica, 36/1, 101-120. Postojna.

Placer, L., 1981: Geološka zgradba jugozahodne Slovenije.- Geologija, 24/1, 27-60, Ljubljana.

Popov, V., 2004: Pliocene small mammals (Mammalia, Lipotyphla, Chiroptera, Lagomorpha, Rodentia) from Muselievo (North Bulgaria).- Geodiversitas, 26, 403-491.
Pruner, P. \& P. Bosák, 2001: Palaeomagnetic and magnetostratigraphic research of cave sediments: theoretical approach, and examples from Slovenia and Slovakia. - Proc., 13th International Speleological Congress, 4th Speleological Congress of Latin America and the Carribean, 26th Brazilian Congress of Speleology, Brasilia, July 15-22, 2001, 1, 9497, Brasilia.

Rabeder, G., 1981: Die Arvicoliden (Rodentia, Mammalia) aus dem Pliozän und dem ältesten Pleistozän von Niederösterreich.- Beiträge zur Paläontologie Österreichs, 10, 1-373, Wien.

Rakovec, I., 1958: Pleistocenski sesalci iz jame pri Črnem kalu.- Razprave, IV, 365-434, Ljubljana.

Reumer, J.W.F., 1984: Ruscinian and early Pleistocene Soricidae (Insectivora, Mammalia) from Tegelen (Netherlands) and Hungary.- Scripta Geologica, 73, 1-173, Leiden.

Rietschel S., Storch G., 1974: Aussergewöhnlich erhaltene Waldmäuse (Apodemus atavus Heller 1936) aus dem Ober-Pliozän von Willershausen am Harz.- Senckebergiana lethaea, 54, 491-519, Frankfurt a. M.

Rzebik-Kowalska. B., 1990: Pliocene and Pleistocene Insectivora (Mammalia) of Poland. VI. Soricidae: Deinsdorfia Heller, 1936 and Zelceina Sulimski, 1962. Acta Zoologica Cracoviensia 33: 45-77.

Rzebik-Kowalska, B., 1998: Fossil History of Shrews in Europe. In: Wojcik, J.M. \& M. Wolsan (Eds.): Evolution of Shrews. Mammal Res. Inst. PAN, pp. 23-92, Białowieża.

Sasowsky, I.D., Šebela, S. \& W. Harbert, 2003: Concurrent tectonism and aquifer evolution $>100,000$ years recorded in cave sediments, Dinaric karst, Slovenia.Environmental Geology, 44, 1, 8-13, New York.

Šebela, S. \& I.D. Sasowsky, 2000: Paleomagnetic dating of sediments in caves opened during highway construction near Kozina, Slovenia.- Acta Carsologica, 29/2, 23, 303-312, Ljubljana.

Storch, G. \& O. Fejfar, 1989: Gundersheim-Findling, a Ruscinian rodent fauna of Asian affinities from Germany. In: Lindsay E.H. et al. (Eds.): European Neogene Mammal Chronology, Plenum Press, pp. 405-412, New York.

Zupan, N., 1991: Flowstone datations in Slovenia.- Acta carsologica, 20, 187-204, Ljubljana.

Zupan Hajna, N., Mihevc, A., Pruner, P. \& P. Bosák, 2005: Nova spoznanja o starosti jamskih sedimentov v Sloveniji.- Geološki zbornik, 18, 132-135, Ljubljana.

Zupan Hajna, N., Mihevc, A., Pruner, P. \& P. Bosák, 2007: Time recorded in cave deposits - 10 years of paleomagnetic research in Slovenian caves.- Acta Carsologica, 36/1, 242, Ljubljana. 